\title{
DOES THE RESIDUAL EFFECT OF N-FERTILIZATION APPLIED ON CORN PHASE MAINTAIN FORAGE PRODUCTION OF THE FOLLOWING PASTURE PHASE IN AN INTEGRATED CROP-LIVESTOCK SYSTEM?
}

\author{
O EFEITO RESIDUAL DA ADUBAÇÃO NITROGENADA APLICADA NA FASE DE \\ MILHO MANTÉM A PRODUÇÃO DE FORRAGEM DA FASE PASTAGEM EM \\ SUCESSÃO EM UM SISTEMA DE INTEGRAÇÃO LAVOURA-PECUÁRIA?
}

\author{
Angela BERNARDON ${ }^{1 *}$; André Brugnara SOARES ${ }^{2}$; Denise Adelaide Gomes ELEJALDE ${ }^{1}$; \\ Tangriani Simioni ASSMANN ${ }^{2}$; Angélica Caroline ZATTA ${ }^{1}$; Lucas CANDIOTTO $^{1}$ \\ 1. Postgraduate Program in Agronomy, Federal Technological University of Paraná, Pato Branco, Paraná, Brazil. 2Department of \\ Agronomy, Federal Technological University of Paraná, Pato Branco, Paraná, Brazil *angela.agro@yahoo.com.br
}

\begin{abstract}
Nutrient cycling represents an important nutrient source in the Integrated CropLivestock Systems (ICLS). In general, only the crop phase of the ICLS is fertilized, however little is known about this residual effect of nitrogen fertilization from summer crop to succeeding winter pasture. This research aimed to evaluate the forage growth dynamic and botanical composition of a mixed pasture of black oat (Avena strigosa Schreb) and ryegrass (Lolium multiflorum Lam.) affected by two canopy height managements (high and low) and nitrogen fertilization applied to either the summer crop (corn) or winter pasture phase of an ICLS. The experiment was established in 2012 in southern Brazil. Black oat and ryegrass were growing during winter season and corn (Zea mays L.) during summer season, being this paper related to the 2014 pasture period. Treatments were composed by two canopy heights $(25$ and $10 \mathrm{~cm})$ and two N-Fertilization Times (N-Pasture or $\mathrm{N}-$-Corn) of $200 \mathrm{~kg}$ of $\mathrm{N} \mathrm{ha}^{-1}$. Canopy height was regulated by beef steers grazing through continuous stocking with a variable stocking rate. Forage mass was lower in the $10 \mathrm{~cm}$ canopy height on average, however this forage mass was composed by greater proportion of ryegrass leaves and lower proportion of dead material in relation to the treatment with $25 \mathrm{~cm}$ canopy height. The $\mathrm{N}$-fertilization applied directly on pasture phase $(\mathrm{N}-$ Pasture) increased forage mass, tiller population density, participation of ryegrass and ryegrass leaf proportion in the forage mass. Furthermore, when pasture was fertilized with $\mathrm{N}$, the forage accumulation rate increased about $69 \%$, highlighting that the corn $\mathrm{N}$-fertilization did not present significant effect on forage productivity. The residual effect of corn $\mathrm{N}$-fertilization was not enough to maintain high forage accumulation. Thus, the pasture $\mathrm{N}$-fertilization is fundamental to keep high-productive crop-livestock system.
\end{abstract}

KEYWORDS: Avena strigosa Schreb. Botanical composition. Continuous stocking. Lolium multiflorum Lam. Nutrient cycling.

\section{INTRODUCTION}

Integrated Crop-Livestock System (ICLS) is defined as an agricultural production system that alternates, in the same area, cultivation of annual or perennial pastures for animal production and crops for grain production (CARVALHO et al., 2014). Furthermore, it is a planned system with rational land use, involving grain production and livestock, with advantages for both (MORAES et al., 2014).

Nutrient cycling represents an important nutrient source in the ICLS (ASSMANN et al., 2017). In these sense, owing to the constant soil cultivation in these agricultural systems (two or three crops by agricultural year), a hypothesis of carryover of fertilization from one crop to another was reported (ASSMANN et al., 2003). In southern Brazil, studies have confirmed a residual effect of nitrogen fertilization applied during winter pasture on subsequent corn crop in summer (SANDINI et al., 2011; SARTOR et al., 2018). Assmann et al. (2003) found that the application of $300 \mathrm{~kg} \mathrm{~N} \mathrm{ha}^{-1}$ to winter pasture resulted in no yield response in corn to further $\mathrm{N}$ fertilization in the summer. With a high corn grain yield of $10 \mathrm{t} \mathrm{ha}^{-1}$, the cycling of $\mathrm{N}$ from winter pasture to corn in summer was effective. According to these authors, most of nitrogen applied during pasture phase was still available to corn in summer, thus the corn $\mathrm{N}$-fertilization would not be necessary due to the efficient nutrient cycling from pasture to corn.

Sartor et al. (2018) explained that the nitrogen fertilizer applied during the winter pasture phase may provide higher forage accumulation and consequently increase animal production, moreover nutrient cycling can improve the following crop 
yield in summer, especially grasses, demonstrating that the fertilization is not restrictive to one crop in the crop-pasture rotation. In this context, a new criteria for nitrogen fertilization recommendation in ICLS is suggested, with better use of $\mathrm{N}$ sources. Thus, the system-level fertilization is a concept that contrasts with the more typical paradigm, the fertilization of individual crop within a rotation, since the main objective of this new concept is improve and maintain long-term soil fertility, considering the nutrient cycling between phases of rotation (BERNARDON et al., 2020).

According to Silva et al. (2014) the presence of grazing cattle during pasture phase of an ICLS can influence nutrient cycling both indirectly and directly. Indirectly, grazing cattle stimulates forage regrowth and increases soil nutrient uptake by pasture, while the return of nutrients to the soil via cattle urine and dung drive nutrient cycling directly (SILVA et al. 2014; ASSMANN et al. 2015). Besides that, the nitrogen exportation from livestock is low, ranging from 4 to $10 \%$ of $\mathrm{N}$ intake (SIMPSON; STOBBS, 1981), returning almost entirely these nutrients to the soil. Despite of that, farmers, in general, give priority to fertilize only the crop phase of the ICLS, and rarely the pasture phases are fertilized In fact, crops like corn can provided a high amount of residues. Mazzilli et al. (2014) found a residue of $8.8 \mathrm{Mg} \mathrm{ha}^{-1}$ provided by corn, however the quantity of nitrogen in this residue was low $\left(0.12 \mathrm{Mg}\right.$ of $\left.\mathrm{N} \mathrm{ha}{ }^{-1}\right)$, which was evidenced by the high $C: N$ ratio of the crop (77.5). In this sense, the high $\mathrm{C}: \mathrm{N}$ ratio of the corn residue and lower temperatures during the pasture growing season (winter), which are known to limit decomposition and the nutrient release rate (GUNTIÑAS et al., 2012), maybe limit the nutrient cycling and pasture growth. Nevertheless, the residual effect of nitrogen fertilization from summer crop to succeeding winter pasture in an ICLS is not well understood.

In addition, pasture canopy structure and composition can vary depending of the management during the pasture phase in an ICLS, with consequences in animal production, as well as the soil conditions and pasture residue for soil surface protection (CARVALHO et al., 2018). Thus, the management of canopy structure is essential, in order to optimize the herbage intake, hence maximize animal production and forage accumulation (KUNRATH et al., 2020). In this context, the suitable management of pasture phase is an imperative factor for the success of ICLS, mainly the pasture fertilization and canopy height management (BALBINOT JUNIOR et al., 2009).

One of the premises of the ICLS is the production of plant biomass during all the year, with a short interval between the phases of the croppasture rotation and without rest periods. In this sense, a mixed pasture of black oat 'BRS 139', with early development, and ryegrass 'Barjumbo', with late development can be a good option to fill the cool season period between the summer crops and provide a longer pasture use period.

There are several studies about canopy height management and pasture nitrogen fertilization in ICLS (PELLEGRINI et al., 2010; KUNRATH et al., 2020). However, most of these researches studied these management strategies in isolation and little is known about the interaction of these factors in the management of an ICLS. Thus, the aim of this research was to evaluate the forage growth dynamic and botanical composition of a mixed pasture of black oat (Avena strigosa Schreb) 'BRS 139' and ryegrass (Lolium multiflorum Lam.) 'Barjumbo' managed with high and low canopy height, and with nitrogen fertilization applied to either the pasture in winter or the crop phase in summer in an ICLS.

\section{MATERIAL AND METHODS}

\section{Location and experimental phases}

The experiment was conducted in Abelardo Luz, Santa Catarina, southern Brazil (26 $31^{\prime} \mathrm{S}, 51^{\circ}$ $35^{\prime} \mathrm{W}, 850 \mathrm{~m}$ high), in an area of 20 ha that has been subject to a long-term ICLS experiment using no-till since 2012. The soil is classified as an Oxisol with a clay texture (EMBRAPA, 2013). The climate type is Cfb, humid subtropical, according to Köppen's Classification (ALVARES et al., 2013). The meteorological data observed throughout the experimental period are shown in Figure 1. 


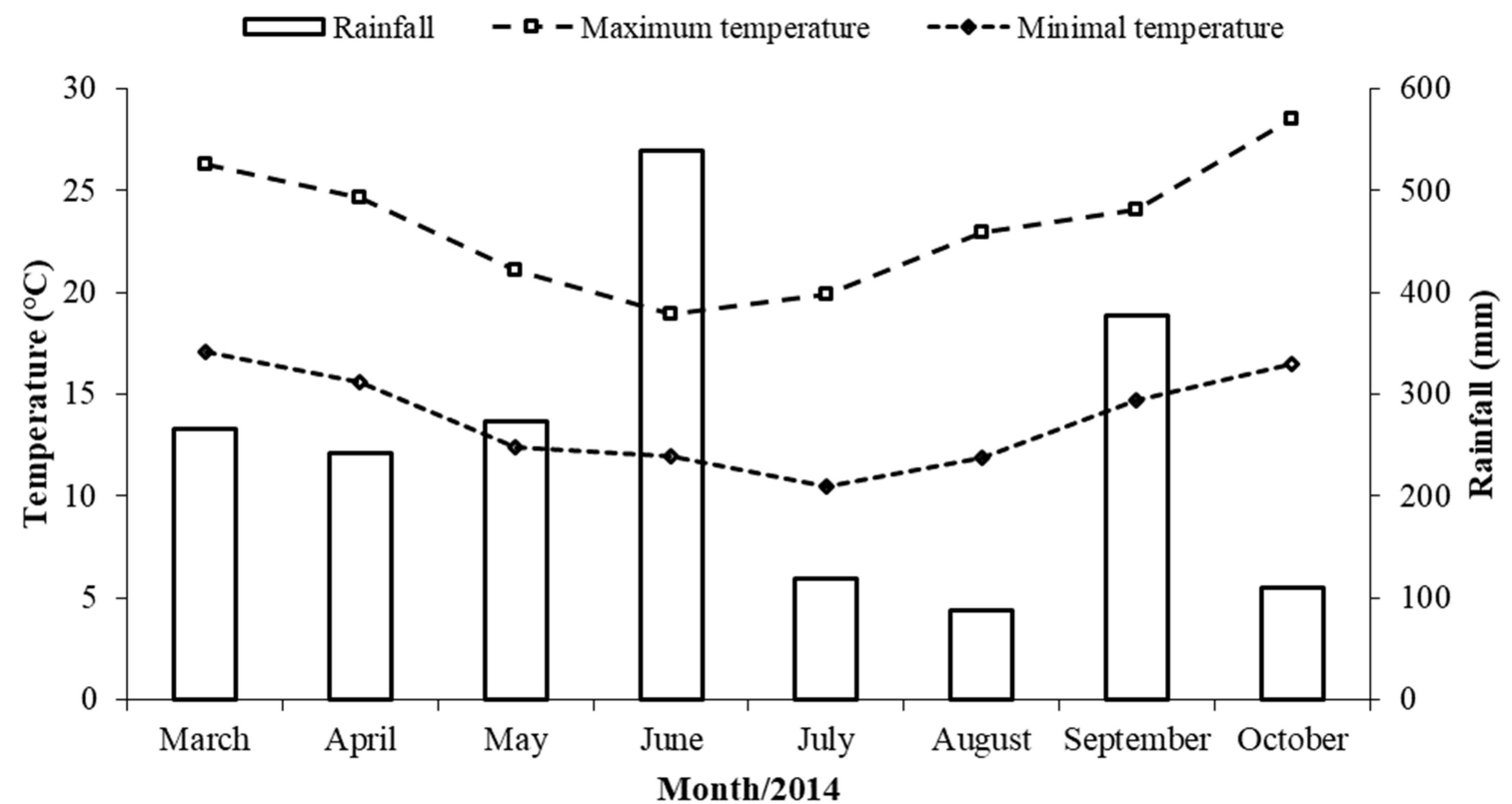

Figure 1. Monthly means of rainfall, maximum and minimal temperature of air during the experiment period in Abelardo Luz, state of Santa Catarina, Brazil. Source: National Institute of Meteorology (INMET).

The soil chemical properties in the $0-0.20 \mathrm{~m}$ soil layer at the time of pasture sowing, in April 2014, are shown in Table 1.

Table 1. Soil chemical properties in the 0-0.20 m soil layer in April 2014.

\begin{tabular}{lllllc}
\hline $\mathrm{pH}$ & Organic Matter & $\mathrm{P}$ & $\mathrm{K}$ & $\mathrm{Al}$ & $\mathrm{CEC}$ \\
\hline $\mathrm{CaCl}_{2}$ & $\mathrm{~g} \mathrm{dm}^{-3}$ & $\mathrm{mg} \mathrm{dm}$ & -3 & - \\
\hline 4.84 & 44.77 & 8.42 & 0.26 & 0.07 & 13.80 \\
\hline
\end{tabular}

$\mathrm{pH}_{-} \mathrm{CaCl}_{2}$ 1:2.5; Organic matter by wet digestion; $\mathrm{P}$ and $\mathrm{K}$ from Mehlich-I solution; exchangeable $\mathrm{Al}$ with $\mathrm{KCl} 1 \mathrm{~mol} \mathrm{~L}{ }^{-1} ; \mathrm{CEC}=\mathrm{Cation}$ Exchange Capacity.

The experiment began with Sorghum bicolor grazing in the summer of 2012/2013 followed by black oat (Avena strigosa) grazing in the winter of 2013. Subsequently, corn (Zea mays L.) was planted for grain production in the summer of $2013 / 2014$. This paper is related to the pasture period of the 2013/14 agricultural year in an ICLS. This agricultural year started when corn hybrid 'Maximus' was sown on 10 October 2013 in a no-till system with $0.8 \mathrm{~m}$ row spacing. After the corn grain harvest, the field was desiccated with application of $1.33 \mathrm{~L} \mathrm{ha}^{-1}$ of glyphosate on 29 March 2014. The mixture of black oat 'BRS 139' and ryegrass 'Barjumbo' was sown on 3 April 2014 using a notillage system, with a spacing of $0.17 \mathrm{~m}$ between rows. Sowing density was 100 and $25 \mathrm{~kg} \mathrm{ha}^{-1}$ of black oat and ryegrass seeds, respectively. At that time, the field was fertilized with $7 \mathrm{~kg}$ of $\mathrm{N} \mathrm{ha}^{-1}$, $70.4 \mathrm{~kg}$ of $\mathrm{P}_{2} \mathrm{O}_{5} \mathrm{ha}^{-1}$ and $63.4 \mathrm{~kg}$ of $\mathrm{K}_{2} \mathrm{O} \mathrm{ha}{ }^{-1}$ of formulated N-P-K.

\section{Experimental design and treatments}

The experimental design was a randomized complete block with three replicates. Treatments were arranged in a factorial arrangement of $2 \times 2$. The first factor consisted of two canopy heights of $25 \mathrm{~cm}$ (high canopy height) and $10 \mathrm{~cm}$ (low canopy height). The canopy height was monitored weekly, using a ruler graduated in centimeters, and the actual average canopy heights during the experimental period were 23.7 and $10.7 \mathrm{~cm}$ for high and low canopy height, respectively.

The second factor, $\mathrm{N}$-fertilization time, represents the system-level fertilization, which in ICLS, consists of the application of nitrogen fertilizer during only one crop phase, in other words, $\mathrm{N}$-fertilization is applied only once in an agricultural year of a crop-pasture rotation system. Therefore, in this study, the $\mathrm{N}$ fertilization (dose of $200 \mathrm{~kg}$ of $\mathrm{N}$ $\mathrm{ha}^{-1}$ ), consisted of two treatments: N-Pasture fertilization or N-Corn fertilization So, in summer (corn phase), the N-Corn plots received $200 \mathrm{~kg}$ of $\mathrm{N}$ 
Does the residual...

$\mathrm{ha}^{-1}$ and the plots denominated N-Pasture, did not received nitrogen fertilization. In winter (pasture phase), on the other hand, the plots denominated $\mathrm{N}$ Pasture received $200 \mathrm{~kg}$ of $\mathrm{N} \mathrm{ha}^{-1}$ and the N-Corn plots did not receive $\mathrm{N}$ fertilization. Thus, the $\mathrm{N}$ Corn plots represented the residual effect of $\mathrm{N}$ fertilization from corn to pasture phase, since the pasture did not receive $\mathrm{N}$-fertilization in this plots, only corn was fertilized with $\mathrm{N}$ in this case.

Nitrogen fertilization of N-Corn plots was applied on 13 November 2013 at V6 stage. Nitrogen fertilization of N-Pasture plots was applied on 8 May 2014, 35 days after the pasture was sown and at the start of tillering. Nitrogen fertilization, for both application times, was applied without splitting in the form of urea $(45 \%$ of $N)$, under favorable weather and soil moisture conditions for the maximum utilization of the fertilizer.

Continuous stocking and variable stocking rate was used, in order to maintain the intended canopy heights. The animals used were Nelore/Charolais steers. The grazing period started in 19 May 2014, when the average canopy height was $30 \mathrm{~cm}$, and lasted 175 days, until 10 November 2014.

\section{Sampling procedures}

Samples of forage mass and forage accumulation were collected each 28 days. The forage mass cuts started in 19 May 2014. However, this first evaluation period (19/05 to $16 / 06)$ was a period of adaptation until the pasture reached the intended canopy heights. So, the pasture botanical composition evaluation started only in 16 June 2014, when the canopy heights treatments were established.

Forage samples were taken at 10 points per plot. Each sampling point corresponded to a metal frame of $0.25 \mathrm{~m}^{2}$. The forage contained within the frame was cut at ground level then dried in a forcedair oven at $55^{\circ} \mathrm{C}$ until constant weight. Once dried, the samples were weighed and the values were converted to $\mathrm{kg}$ of dry matter per hectare $(\mathrm{kg}$ of DM $\mathrm{ha}^{-1}$.
BERNARDON, A. et al.

Tiller Population Density (TPD) was obtained by count of tillers inside a sample framework with $0.15 \mathrm{~m}^{2}$ at six representative points per plot. Canopy samples for botanical composition and morphological components were cut at ground level at six points per plot. The forage samples were separated into botanical components (black oat and ryegrass), morphological components (leaf blade and stem + sheath) and dead material. Once separated, the materials were dried in an oven by forced air circulation at $55{ }^{\circ} \mathrm{C}$ for $72 \mathrm{~h}$, and then they were weight. The proportion of each component in the forage mass was obtained dividing the dry weight of each component by the forage dry mass. Daily forage accumulation rate $(\mathrm{kg}$ of DM ha ${ }^{1}$ day $^{-1}$ ) also was assessed each 28 days, according to technique described by Klingman, Miles and Mott (1943), using three grazing exclusion cage per plot.

\section{Statistical analysis}

The data were subjected to an analysis of variance with PROC MIXED in SAS®, the means were estimated by LSMEANS function, and these findings were compared using LSD test at 5\% probability of error. The canopy height and $\mathrm{N}$ fertilization time factors and their interaction were considered as a fixed effect, and the evaluation periods were analyzed as repeated measures in time, entering as random component in the model as well as the block.

\section{RESULTS AND DISCUSSION}

\section{Forage mass and botanical composition}

The forage mass varied as a function of the interaction between canopy height and evaluation period $(\mathrm{P}=0.0004)$. As expected, in almost all of evaluation periods, the forage mass was higher in the $25 \mathrm{~cm}$ canopy than in the $10 \mathrm{~cm}$ management. In addition, there was a significant increase in the forage mass values from $11 / 08$ in both canopy height managements (Table 2).

Table 2. Forage mass and botanical composition of a mixed pasture of black oat 'BRS 139' and ryegrass 'Barjumbo' managed with two canopy heights in the evaluation periods.

\begin{tabular}{|c|c|c|c|c|c|c|}
\hline \multirow[b]{2}{*}{$\begin{array}{l}\text { Canopy } \\
\text { Height }\end{array}$} & \multicolumn{6}{|c|}{ Evaluation Periods } \\
\hline & $\begin{array}{l}19 / 05- \\
16 / 06^{*}\end{array}$ & $16 / 06-14 / 07$ & $14 / 07-11 / 08$ & $11 / 08-08 / 09$ & $08 / 09-06 / 10$ & $06 / 10-03 / 11$ \\
\hline & \multicolumn{6}{|c|}{ Forage Mass (kg of DM ha $\left.{ }^{-1}\right)$} \\
\hline $25 \mathrm{~cm}$ & $1507 \mathrm{Ad}$ & $1936 \mathrm{Ac}$ & $2544 \mathrm{Ab}$ & $3005 \mathrm{Aa}$ & $2978 \mathrm{Aab}$ & $3239 \mathrm{Aa}$ \\
\hline $10 \mathrm{~cm}$ & $1111 \mathrm{Bb}$ & $950 \mathrm{Bb}$ & $1206 \mathrm{Bb}$ & $1775 \mathrm{Ba}$ & $2240 \mathrm{Ba}$ & $2353 \mathrm{Aa}$ \\
\hline
\end{tabular}

Black Oat 'BRS 139' (\%) 
Does the residual...

BERNARDON, A. et al.

\begin{tabular}{|c|c|c|c|c|c|}
\hline $25 \mathrm{~cm}$ & $57.6 \mathrm{Aa}$ & $41.5 \mathrm{Ab}$ & $6.2 \mathrm{Ac}$ & - & - \\
\hline $10 \mathrm{~cm}$ & $44.3 \mathrm{Ba}$ & $22.3 \mathrm{Bb}$ & $4.3 \mathrm{Ac}$ & - & - \\
\hline \multicolumn{6}{|c|}{ Ryegrass 'Barjumbo' (\%) } \\
\hline $25 \mathrm{~cm}$ & $18.8 \mathrm{Ad}$ & $29.7 \mathrm{Bd}$ & $45.0 \mathrm{Bc}$ & $64.0 \mathrm{Bb}$ & $77.4 \mathrm{Aa}$ \\
\hline $10 \mathrm{~cm}$ & $18.4 \mathrm{Ac}$ & $48.6 \mathrm{Ab}$ & $74.1 \mathrm{Aa}$ & 81.9 Aa & $79.0 \mathrm{Aa}$ \\
\hline \multicolumn{6}{|c|}{ Dead Material (\%) } \\
\hline $25 \mathrm{~cm}$ & $23.6 \mathrm{Ac}$ & $28.8 \mathrm{Abc}$ & $48.7 \mathrm{Aa}$ & $36.0 \mathrm{Ab}$ & $22.6 \mathrm{Ac}$ \\
\hline $10 \mathrm{~cm}$ & $37.3 \mathrm{Aa}$ & $29.1 \mathrm{Aa}$ & $21.6 \mathrm{Bb}$ & $18.0 \mathrm{Bb}$ & $21.0 \mathrm{Ab}$ \\
\hline \multicolumn{6}{|c|}{ Black oat leaf (\%) } \\
\hline $25 \mathrm{~cm}$ & $23.0 \mathrm{Aa}$ & $10.6 \mathrm{Ab}$ & $1.6 \mathrm{Ac}$ & - & - \\
\hline $10 \mathrm{~cm}$ & $15.8 \mathrm{Ba}$ & $7.8 \mathrm{Ab}$ & $1.6 \mathrm{Ac}$ & - & - \\
\hline \multicolumn{6}{|c|}{ Black oat stem (\%) } \\
\hline $25 \mathrm{~cm}$ & $34.6 \mathrm{Aa}$ & $30.9 \mathrm{Aa}$ & $3.2 \mathrm{Ab}$ & - & - \\
\hline $10 \mathrm{~cm}$ & $28.5 \mathrm{Aa}$ & $14.6 \mathrm{Bb}$ & $2.7 \mathrm{Ac}$ & - & - \\
\hline \multicolumn{6}{|c|}{ Ryegrass leaf (\%) } \\
\hline $25 \mathrm{~cm}$ & $14.5 \mathrm{Ad}$ & $22.4 \mathrm{Bcd}$ & $30.2 \mathrm{Bbc}$ & $40.1 \mathrm{Ba}$ & $32.8 \mathrm{Aab}$ \\
\hline $10 \mathrm{~cm}$ & 14.1 Ac & $38.6 \mathrm{Ab}$ & $56.8 \mathrm{Aa}$ & $55.9 \mathrm{Aa}$ & $39.3 \mathrm{Ab}$ \\
\hline
\end{tabular}

Ryegrass stem (\%)

$\begin{array}{llllll}\text { Average } & 4.3 \mathrm{e} & 8.7 \mathrm{~d} & 16.8 \mathrm{c} & 26.0 \mathrm{~b} & 40.0 \mathrm{a}\end{array}$

Means followed by the same letter, upper-case within columns and lower-case within rows, do not differ significantly according to LSD test at $5 \%$ of probability. *Adaptation period until the pasture reached the intended canopy heights.

In relation to the pasture botanical and morphological composition, Aguinaga et al. (2008) reported that the pasture management may have effect on the dynamics of participation of species and the morphological characteristics of forage plants. In our study, there was effect of the canopy height management for pasture botanical and morphological composition. It was observed an interaction between canopy height and evaluation period for proportions of black oat 'BRS 139' $(\mathrm{P}=$ $0.0244)$, ryegrass 'Barjumbo' $(P=0.0020)$ and dead material $(\mathrm{P}<0.0001)$ in the forage mass.

A decrease in black oat participation was observed while the percentage of annual ryegrass increased with time (Table 2). In addition, the ryegrass increased the participation in the forage mass earlier in the low than in the high canopy height. According to Fontanelli et al. (2012), the ryegrass supports management with lower canopy height than black oat and can perform better under higher grazing intensity.

Regarding the ryegrass proportion in the forage mass, there was a significant difference between 25 and $10 \mathrm{~cm}$ canopy heights from 14/07 to $06 / 10$. In these periods, the ryegrass proportion was higher in the low canopy height than in the high canopy height management (Table 2). This probably occurred because the more intense grazing of black oat, in the low canopy height, reduced shading of the black oat on the ryegrass and opened the canopy to incidence of solar radiation on closer to the ground surface, stimulating the ryegrass tillering. Since the black oat proportion in the forage mass was lower in the $10 \mathrm{~cm}$ management compared with the $25 \mathrm{~cm}$ canopy height (Table 2).

There was an increase for dead material proportion in the $25 \mathrm{~cm}$ canopy height compared to $10 \mathrm{~cm}$ management from 11/08 to $06 / 10$ (Table 2). This result can be explained by the end of black oat development cycle in these periods (11/08 to 08/09 and $08 / 09$ to $06 / 10$ ), with more senescence of plants in the high canopy height, in which the proportion of black oat was higher. Moreover, in a study carried out by Pontes et al. (2004), the senescence flux of ryegrass increased linearly with canopy height $(5$ to $20 \mathrm{~cm})$. The authors explain that, in the higher canopy heights, a higher proportion of the forage accumulated was used to maintain canopy height, hence there are greater losses by senescence, thereby pastures submitted to intense defoliation, in general, show lower growth but lower tissue senescence too.

Some authors also associate the senescence flux with the stocking rate, since the higher 
stocking, in the low canopy height, increases the probability of individual leaf defoliation. Lemaire and Agnusdei (1999) observed that $40 \%$ of leaves were not defoliated before starting the senescence in Paspalum dilatatum and Lolium multiflorum pastures kept with low canopy height, while around $75 \%$ of leaves escaped of defoliation in the high canopy height management. Therefore, the greater defoliation intensity can reduce losses by senescence.

Despite that, minimize forage losses by senescence is not the focus of pasture management, and also will not provide greater gains in animal production (PEREIRA et al., 2015). Besides that, the dead material can not be considered as "lost" in an agricultural production system, since this material will decompose and return to soil, incorporating carbon and cycling nutrients (ASSMANN et al., 2014). Thus, the nutrient cycling, in the pasture phase, starts when the first leaf senesces and returns to soil in form of nutrients and organic matter, thereby the nutrient cycling occurs constantly throughout the grazing period. According to Ribeiro et al. (2019), the grazing period in an ICLS can increase the soil carbon stock and accelerate the nutrient cycling due to the continuous pasture growth and the higher forage yield stimulated by grazing.

Among the evaluation periods, the black oat 'BRS 139' showed the highest proportion in the first evaluation period (16/06 to 14/07), both in high and low canopy height managements (Table 2). However, there was a decrease in the black oat proportion with advancing the pasture use period, since the black oat represented, on average, only $5 \%$ of the forage mass in the period between 11/08 and 08/09, disappearing in September. This result highlights the early production of black oat 'BRS 139', which is an option to fill the lack of forage from the end of autumn and beginning of winter, period that the ryegrass shows low production (AGUINAGA et al., 2008).

The ryegrass 'Barjumbo' showed higher proportion in the forage mass from August (third period) in the low canopy height, since the proportion did not differ from the latest periods in this management. On the other hand, in the high canopy height, the ryegrass proportion increased from September (Table 2).

Similar results were found by Aiolfi et al. (2015), who observed higher forage production of ryegrass 'Barjumbo' from September until November in Palmas, state of Santa Catarina, Southern Brazil. According to Müller et al. (2009), the base temperature of tetraploid ryegrass genotypes, such as 'Barjumbo', is higher than diploid genotypes and varies from 9 to $10.6{ }^{\circ} \mathrm{C}$. Thus, the tetraploid ryegrass genotypes show a slow initial growth with the low temperatures and increase the forage production when the temperatures are higher, in the spring season.

The mixed pasture of black oat 'BRS 139', with early development, and ryegrass 'Barjumbo', with late development, provided higher forage yield and a longer pasture use period, since the grazing period with continuous stocking lasted 175 days. Thereby, the forage planning in an ICLS is a keyissue. In our study was possible to utilize the longevity of tetraploid ryegrass 'Barjumbo' production until November due to the soybean cultivation in sequence to pasture, since the recommended soybean sowing time is between middle of October to end of November for west of Santa Catarina.

Regarding the pasture morphological composition, the black oat leaf and stem proportions in the forage mass presented the same behavior than black oat proportion (Table 2). It is important to notice the low leaf/stem ratio of black oat, with an average of 0.5 . Thus, in general, black oat presented twice stem mass than leaf in the canopy.

There was an interaction between canopy height and evaluation period for ryegrass leaf proportion in the forage mass $(\mathrm{P}=0.0018)$. There was significant difference between canopy height treatments from $14 / 07$ to $06 / 10$. In these periods, the ryegrass leaf proportion was higher in the low canopy height (Table 2).

In a study carried out by Cauduro et al. (2006), the ryegrass grazed with continuous stocking showed the same number of green leaves per tiller, lower length of leaves and higher tiller density in low canopy height management. Thus, the possible higher tiller density in the low canopy height management results in a higher amount of shorter leaves, in relation to high canopy height.

In both high and low canopy height treatments was observed an increase of ryegrass leaf proportion in the periods with more intense ryegrass yield, from $11 / 08$ to $06 / 10$ (Table 2). In these periods, on average, $56 \%$ of forage mass was composed by ryegrass leaves in the low canopy height. In the last evaluation period, there was a decrease of the ryegrass leaf proportion, possibly, due to the higher air temperatures in middle of October and final of ryegrass vegetative cycle, since the maximum air temperature was $28.5^{\circ} \mathrm{C}$ in October (Figure 1). In addition, the ryegrass stem proportion in the forage mass increased $(\mathrm{P}<0.0001)$ 
in the last evaluation period (Table 2), which also indicated the end of the ryegrass productive cycle.

The forage mass also varied as a function of $\mathrm{N}$ fertilization time $(\mathrm{P}=0.0189)$, since the $\mathrm{N}$ Pasture treatment presented higher forage mass compared with N-Corn treatment (Table 3). In addition, there was an interaction between $\mathrm{N}$ Fertilization time and evaluation period for black oat 'BRS 139' $(\mathrm{P}=0.0437)$ and dead material $(\mathrm{P}<$ $0.0001)$ proportions and effect of $\mathrm{N}$ fertilization time $(\mathrm{P}<0.0001)$ for ryegrass 'Barjumbo' proportion in the forage mass.

Table 3. Forage mass and botanical composition of a mixed pasture of black oat 'BRS 139' and ryegrass 'Barjumbo' with $\mathrm{N}$ fertilization applied during either the corn crop or the pasture phase in an Integrated Crop-Livestock System in the evaluation periods.

\begin{tabular}{|c|c|c|c|c|c|}
\hline \multirow{2}{*}{ N Fertilization } & \multicolumn{5}{|c|}{ Evaluation Periods } \\
\hline & $16 / 06-14 / 07$ & $14 / 07-11 / 08$ & $11 / 08-08 / 09$ & $08 / 09-06 / 10$ & $06 / 10-03 / 11$ \\
\hline & \multicolumn{5}{|c|}{ Forage Mass (kg of DM ha ${ }^{-1}$ ) } \\
\hline N-Pasture & $2200 \mathrm{~A}$ & & & & \\
\hline \multirow[t]{2}{*}{ N-Corn } & $1940 \mathrm{~B}$ & & & & \\
\hline & \multicolumn{5}{|c|}{ Black Oat 'BRS 139' (\%) } \\
\hline N-Pasture & $47.9 \mathrm{Aa}$ & $22.2 \mathrm{Bb}$ & $4.8 \mathrm{Ac}$ & - & - \\
\hline N-Corn & $54.0 \mathrm{Aa}$ & $41.7 \mathrm{Aa}$ & $5.7 \mathrm{Ab}$ & - & - \\
\hline $\begin{array}{l}\text { N-Pasture } \\
\text { N-Corn }\end{array}$ & $\begin{array}{l}\text { Ryegrass 'BaI } \\
60.6 \mathrm{~A} \\
46.7 \mathrm{~B}\end{array}$ & mbo' (\%) & & & \\
\hline N-Corn & \multicolumn{5}{|c|}{ Dead Material (\%) } \\
\hline N-Pasture & $31.7 \mathrm{Aa}$ & $32.3 \mathrm{Aa}$ & $23.1 \mathrm{Bb}$ & $16.8 \mathrm{Bb}$ & 18.1 Ab \\
\hline \multirow[t]{2}{*}{ N-Corn } & $29.2 \mathrm{Abc}$ & $25.6 \mathrm{Ac}$ & 47.2 Aa & 37.2 Aab & $25.5 \mathrm{Ac}$ \\
\hline & \multicolumn{5}{|c|}{ Black oat leaf $(\%)$} \\
\hline N-Pasture & $16.6 \mathrm{Ba}$ & $5.7 \mathrm{Bb}$ & $1.8 \mathrm{Ac}$ & - & - \\
\hline \multirow[t]{2}{*}{ N-Corn } & $22.2 \mathrm{Aa}$ & $12.7 \mathrm{Ab}$ & $1.5 \mathrm{Ac}$ & - & - \\
\hline & \multicolumn{5}{|c|}{ Ryegrass leaf $(\%)$} \\
\hline N-Pasture & $15.4 \mathrm{Ac}$ & $35.1 \mathrm{Ab}$ & $53.4 \mathrm{Aa}$ & $56.5 \mathrm{Aa}$ & $38.6 \mathrm{Ab}$ \\
\hline N-Corn & 13.2 Ac & $25.9 \mathrm{Bb}$ & 33.7 Bab & $39.5 \mathrm{Ba}$ & 33.5 Aab \\
\hline
\end{tabular}

Means followed by the same letter, upper-case within columns and lower-case within rows, do not differ significantly according to LSD test at $5 \%$ of probability.

The black oat proportion was higher in the $\mathrm{N}$-Corn compared to N-Pasture treatment in the second evaluation period (Table 3 ). In contrast, the ryegrass showed, on average, higher proportion in the N-Pasture treatment, which highlights the high response of ryegrass 'Barjumbo' to $\mathrm{N}$ fertilization applied on pasture. Thus, the ryegrass 'Barjumbo' may have been more competitive in the N-Pasture treatment and interfered in the $\mathrm{N}$ uptake and growth of black oat 'BRS 139' in the mixture. Similar results were found by Assmann et al. (2004), who observed a ryegrass percentage ranging from $80.5 \%$ to $92.5 \%$ respectively to the nitrogen fertilization ranged from 0 to $300 \mathrm{~kg}$ of $\mathrm{N} \mathrm{ha}^{-1}$, in turn, the black oat percentage was reduced from $11 \%$ to $2.8 \%$, in October.
Dead material proportion was higher in the $\mathrm{N}$-Corn compared to N-Pasture treatment from $11 / 08$ to $06 / 10$ (Table 3). Thereby, the higher black oat proportion in the $\mathrm{N}$-Corn treatment and the subsequent senescence of black oat from August increased the amount of dead material in this treatment. Besides that, the black oat litter may have been decomposed more slowly in the N-Corn treatment due to higher carbon/nitrogen ratio compared to litter in the N-Pasture treatment (APOLINÁRIO et al., 2014). Therefore, when the pasture was not fertilized with $\mathrm{N}$ in the ICLS, the nutrient cycling can have been reduced in the system (ANGHINONI; CARVALHO; COSTA, 2013). 
Basso et al. (2010) also reported that the leaf senescence rate decreased with $\mathrm{N}$ supply of Panicum maximum. The authors explain that this positive effect of $\mathrm{N}$ supply on decrease of leaf senescence rate may be associated with the maintenance of leaf photosynthetic capacity for longer time, which reduces the need for internal $\mathrm{N}$ remobilization from older leaves to younger leaves. According to Lemaire and Chapman (1996), this $\mathrm{N}$ remobilization is a process that follows the leaf senescence. Therefore, the deficit of $\mathrm{N}$ can demand for a greater internal $\mathrm{N}$ remobilization by leaves in the pasture not fertilized with $\mathrm{N}$ (N-Corn plots).

Ryegrass leaf proportion also varied as a function of the interaction between $\mathrm{N}$ Fertilization time and evaluation period $(\mathrm{P}=0.0431)$. Regarding pasture morphological composition, keeping forage mass with high proportion of leaves is desirable, since the leaves produce the energy required to plant growth and serve as feed to ruminants (PONTES et al., 2003; ROMAN et al., 2007; PELLEGRINI et al., 2010). In this context, the $\mathrm{N}$ fertilization applied during the pasture phase (N-Pasture plots) increased the ryegrass leaf proportion in the periods with higher ryegrass growth (from 11/08 to 06/10) (Table 3 ). In these periods, about $55 \%$ of forage mass was composed by ryegrass leaves in the N-Pasture treatment (Table 3). The nitrogen influences directly on the morphogenetic traits of forage plants. This nutrient promotes cell division and growth, thus the leaf appearance and elongation rate increase by nitrogen supply (PEREIRA et al., 2015).

\section{Tiller Population Density}

There was an interaction between canopy height and N Fertilization time for Tiller Population Density (TPD) $(\mathrm{P}=0.0120)$. When the $\mathrm{N}$ fertilization was applied on pasture, there was no difference between high and low canopy height. However, when $\mathrm{N}$ was applied on corn (N-Corn plots), there was difference between high and low canopy height, with 409 tillers $\mathrm{m}^{-2}$ more in the low canopy height (Table 4). Between N-Pasture and NCorn treatments, there was difference only in the high canopy height management. The N-Pasture treatment showed 528 tillers $\mathrm{m}^{-2}$ more than $\mathrm{N}$-Corn, with $25 \mathrm{~cm}$ management (Table 4).

Table 4. Tiller Population Density (tillers $\mathrm{m}^{-2}$ ) of a mixed pasture of black oat 'BRS 139' and ryegrass 'Barjumbo' managed with two canopy heights and with $\mathrm{N}$ fertilization applied during either the corn crop or the pasture phase in an Integrated Crop-Livestock System.

\begin{tabular}{lll}
\hline & N-Pasture & N-Corn \\
\cline { 2 - 3 } & Tillers $\mathbf{~ m}^{-2}$ & \\
\hline High canopy height & $1916 \mathrm{Aa}$ & $1388 \mathrm{Bb}$ \\
Low canopy height & $1914 \mathrm{Aa}$ & $1797 \mathrm{Aa}$ \\
\hline
\end{tabular}

Means followed by the same letter, upper-case within columns and lower-case within rows, do not differ significantly according to LSD test at $5 \%$ of probability.

Tillers production is a continuous process that can be accelerated by defoliation and consequent improvement of the luminous environment on the canopy base (DA SILVA; SBRISSIA; PEREIRA, 2015). Casagrande et al. (2010) reported a reduction in the TPD of palisade grass in the treatment with higher forage supply $(13 \%)$. The authors attributed this result to higher canopy height and the consequent decrease of tillering process by low intensity and quality of light incident on the canopy base. Sbrissia and Silva (2008) also reported a decrease in number of tillers as pasture is kept higher. However, these authors also found an increase in the dry mass of tillers with increasing canopy height of Brachiaria brizantha 'Marandu' (10 to $40 \mathrm{~cm}$ ), which showed a selfthinning mechanism in pastures, characterized by high tiller population densities associated with small and light tillers in management with low canopy height and vice-versa.
The main environmental factors that affect the pasture tillering are temperature, light and availability of water and nutrients (PORTELA; PEDREIRA; BRAGA, 2011). The availability of nutrients, like nitrogen, probably, was lower when $\mathrm{N}$ was considered available only from carryover from the corn phase, in the N-Corn treatment, since the pasture was not fertilized directly with $\mathrm{N}$ in this treatment. Thereby, the stimulus for greater tillering, in the N-Corn treatment, may have been happened due to more frequent defoliation in the low canopy height. In this management, a larger number of buds may have been activated and began its development by consequence of the greater intensity and quality of the light incident on the canopy base.

The main physiological adaptation of plants after defoliation is to allocate carbon to apical meristems of tillers and leaf expansion zones in order to maximize the appearance and elongation of new leaves (DA SILVA; SBRISSIA; PEREIRA, 
Does the residual...

2015). Thus, the forage plants, in general, produce shorter leaves and the TPD is high in management with low canopy height, in contrast, the plants tend to develop longer leaves and reduce the tillering rate in the high canopy height (PONTES et al., 2003).

There was no difference between high and low canopy height in the N-Pasture treatment for TDP (Table 4). This result can be explained by Caminha et al. (2010), who reported that most of buds develop into tillers when the $\mathrm{N}$ supply is adequate and there is no severe competition for space between plants. According to the same authors, when plants are well provided by N, less importance plays the quality and intensity of light radiation.

In a study carried out by Pellegrini et al. (2010), the TDP of ryegrass increased linearly with increasing dose of $\mathrm{N}$ fertilization $(0$ to $225 \mathrm{~kg}$ of N $\mathrm{ha}^{-1}$ ). The authors explained that this effect depends of the leaf appearance rate, since each leaf carries an axillary bud, which can develop into a new tiller, depending of environmental conditions, such as light and nutrients.
BERNARDON, A. et al.

Thus, according to the results showed in table 4, the constant defoliation, probably, provided light entering into the canopy base in both high and low canopy height managements in the N-Pasture treatment. Besides that, the greater availability of $\mathrm{N}$, in N-Pasture, possibly increased the number of active buds and hence increased the TPD (BASSO et al., 2010), in the high canopy height. On the other hand, under low nutrient availability in the N-Corn treatment, the pasture sought compensation mechanisms to allocate carbon and recover the leaf area defoliated, with higher tillering in the management with low canopy height.

\section{Daily forage accumulation rate}

Daily Forage Accumulation Rate (DFAR) varied as a function of the interaction between $\mathrm{N}$ Fertilization time and evaluation period $(\mathrm{P}<$ 0.0001). On average, in the N-Pasture treatment, the DFAR was $69 \%$ higher than in the N-Corn (Table 5).

Table 5. Daily forage accumulation rate $\left(\mathrm{kg}\right.$ of $\left.\mathrm{DM} \mathrm{ha}^{-1} \mathrm{day}^{-1}\right)$ of a mixed pasture of black oat 'BRS 139' and ryegrass 'Barjumbo' with $\mathrm{N}$ fertilization applied during either the corn crop or the pasture phase in an Integrated Crop-Livestock System in seven evaluation periods.

\begin{tabular}{|c|c|c|c|c|c|c|c|c|}
\hline \multirow[b]{2}{*}{$\mathbf{N}$} & \multicolumn{7}{|c|}{ Evaluation Period } & \multirow[b]{2}{*}{ Average } \\
\hline & $\begin{array}{l}09 / 04- \\
19 / 05^{*}\end{array}$ & $\begin{array}{l}19 / 05 \\
16 / 06\end{array}$ & $\begin{array}{r}16 / 06 \\
14 / 07\end{array}$ & $\begin{array}{r}14 / 07 \\
11 / 08\end{array}$ & $\begin{array}{r}11 / 08 \\
08 / 09\end{array}$ & $\begin{array}{rr}- & 08 / 09 \\
& 06 / 10\end{array}$ & $\begin{array}{rr}-06 / 10 \\
03 / 11\end{array}$ & \\
\hline \multicolumn{9}{|c|}{ Daily Forage Accumulation Rate (kg of DM ha ${ }^{-1}$ day $^{-1}$ ) } \\
\hline NP & $37.7 \mathrm{Ad}$ & $56.4 \mathrm{Ac}$ & $58.8 \mathrm{Abc}$ & $69.1 \mathrm{Abc}$ & $85.9 \mathrm{Aab}$ & $78.5 \mathrm{Aab}$ & $93.4 \mathrm{Aa}$ & 68.6 \\
\hline $\mathrm{NC}$ & $28.9 \mathrm{Bb}$ & $26.3 \mathrm{Bb}$ & $48.7 \mathrm{Aa}$ & $48.3 \mathrm{Ba}$ & $36.8 \mathrm{Bab}$ & $52.7 \mathrm{Ba}$ & $42.5 \mathrm{Ba}$ & 40.6 \\
\hline
\end{tabular}

Means followed by the same letter, upper-case within columns and lower-case within rows, do not differ significantly according to LSD test at 5\% of probability. NP: N-Pasture; NC: N-Corn. * Daily forage accumulation rate between pasture sowing and animal entrance in the paddocks.

The accumulation rate $\left(\mathrm{kg}\right.$ of $\left.\mathrm{DM} \mathrm{ha}^{-1} \mathrm{day}^{-1}\right)$ was lower in the pasture unfertilized with $\mathrm{N}(\mathrm{N}-$ Corn plots) since the first evaluation period (Table 5). The higher forage production in the pasture fertilized (N-Pasture plots), in the beginning of growth period, is important for accumulation of carbohydrate reserves and formation of suitable leaf area index in order to optimize the photosynthesis, tillering and the regrowth in the next periods (DA SILVA; SBRISSIA; PEREIRA, 2015).

There was no difference between N-Pasture and $\mathrm{N}$-Corn treatments for forage accumulation rate only in the third period (16/06 to 14/07). This result can be explained by the increase in the accumulation rate in the N-Corn plots from the third period (Table $5)$.

In the initial evaluation periods, the lower forage accumulation in the $\mathrm{N}$-Corn treatment can be explained by $\mathrm{N}$ immobilization, owing to high carbon/nitrogen ratio of corn residue (MAZZILLI et al., 2014). However, in the third evaluation period, there was an increase of daily forage accumulation in the N-Corn. This probably occurred due to grazing effect in this period. The constant plant defoliation by grazing improves the leaf area index and modifies the canopy structure, which promotes a more efficient light capture by canopy, compared to plants not grazed (MCNAUGHTON, 1983).

From the third period, there was no difference among the evaluation periods for DFAD in the N-Corn treatment. The favorable conditions of rainfall and air temperature (Figure 1) allowed a constant accumulation rate until the end of grazing period in this treatment.

On the other hand, in the N-Pasture treatment, there was an increase of DFAR in the last 
three evaluation periods (Table 5). In these periods, the DFAR in N-Pasture was 133; 49 and $120 \%$ higher than the DFAR in N-Corn treatment, respectively. The intense ryegrass development from August influenced this increase of DFAR in NPasture treatment, since the ryegrass 'Barjumbo' showed high productive response to $\mathrm{N}$ fertilization.

Lupatini et al. (2013) also reported an increase in the DFAR during the grazing period of a mixed pasture of black oat and ryegrass fertilized with 150 and $300 \mathrm{~kg}$ of $\mathrm{N} \mathrm{ha}^{-1}$. According to the authors, it is possible keeping a high forage accumulation until the end of grazing period with pasture $\mathrm{N}$ fertilization and this management is important, mainly in the ICLS, since keeps a high animal weight gain and increases the amount of pasture stubble for no-till system maintenance.

We also observed the maintenance in the soil of the $\mathrm{N}$ applied at beginning of pasture tillering. Even 94 days after $\mathrm{N}$ fertilization of $\mathrm{N}$ Pasture plots, the DFAR in N-Pasture was $133 \%$ higher than the DFAR in N-Corn treatment, and this behavior was observed until the end of grazing period, i.e. 178 days after pasture $\mathrm{N}$ fertilization. Sandini et al. (2011) reported the effect of the N applied on pasture in the DFAR evaluated 143 days after pasture $\mathrm{N}$ fertilization, as well as residual effect of the $\mathrm{N}$ applied on pasture in the corn yield in succession.

In southern Brazil, studies demonstrated that the $\mathrm{N}$ applied during pasture phase of the ICLS, kept available to following summer crop, mainly due to the efficient nutrient cycling from pasture to corn (ASSMANN et al., 2003; SANDINI et al., 2011; SARTOR et al., 2018). On the other hand, in our study, the residual effect of the $\mathrm{N}$ applied during the corn phase (N-Corn plots) appeared not to be enough to maintain the high forage accumulation rate of this black oat and ryegrass mixture. Intensive production systems, such as the ICLS, have the processes of production, nutrient exportation and nutrient cycling accelerated, which increases the nutrients demand, mainly the nitrogen in case of pastures, due to the constant tissue turnover after grazing (ASSMANN et al., 2015). In summary, when $\mathrm{N}$ was available, only from carryover from the corn phase, in the N-Corn treatment, the leaf proportion in forage mass and tiller population density were reduced, with consequent lower forage mass and forage accumulation, which became the ICLS less productive.

\section{CONCLUSIONS}

The early production of the black oat 'BRS 139' (June to August) with the late production of the tetraploid ryegrass 'Barjumbo' (September to November) in a mixed canopy allowed almost six months of grazing period with continuous stocking. Management of nitrogen fertilization and canopy height modified the pasture botanical and morphological composition. Although the forage mass was lower in the $10 \mathrm{~cm}$ canopy height, the dead material proportion in this forage mass was lower and the proportions of ryegrass 'Barjumbo' and ryegrass leaves were higher in this management. Besides the ryegrass performed better than black oat in the low canopy height, this species also showed high response to $\mathrm{N}$ fertilization applied on pasture (N-Pasture plots). The N-fertilization during the pasture phase increased forage mass and proportions of ryegrass 'Barjumbo' and ryegrass leaves in this mass. In the high canopy height, the pasture Nfertilization also provided greater tiller population density.

The daily forage accumulation rate increased more than twice when the pasture was fertilized with $\mathrm{N}$ (N-Pasture plots), especially in the periods with higher ryegrass proportion in the forage mass (August to November). Therefore, the residual effect of the $\mathrm{N}$ applied during the corn phase (N-Corn plots) was not enough to maintain the high production potential of the mixed pasture of black oat 'BRS 139' and ryegrass 'Barjumbo'. This research data showed that the nitrogen fertilization during the pasture phase of an Integrated CropLivestock System is a key-issue in order to maintain the high production potential of this agricultural systems.

RESUMO: A ciclagem de nutrientes representa uma importante fonte de nutrientes em sistemas de Integração Lavoura-Pecuária (ILP). Em geral, apenas a fase de lavoura é fertilizada, entretanto pouco se sabe sobre esse efeito residual da adubação nitrogenada realizada na lavoura de verão para as pastagens de inverno em sucessão. Esse trabalho objetivou avaliar a dinâmica de acúmulo de forragem e a composição botânica de uma pastagem mista de aveia preta (Avena strigosa Schreb) e azevém (Lolium multiflorum Lam.) manejada com duas alturas do pasto (alta e baixa) e com adubação nitrogenada realizada na cultura de grãos (milho) ou na fase pastagem de um sistema ILP. O experimento foi estabelecido em 2012 no sul do Brasil. Aveia preta e azevém eram cultivados durante o inverno e milho para grãos (Zea mays L.) era cultivado durante o verão, 
sendo esse trabalho relacionado ao período de pastagem em 2014. Os tratamentos foram compostos por duas alturas de manejo do pasto $(25$ e $10 \mathrm{~cm}$ ) e duas épocas de adubação nitrogenada no sistema ILP (N-Pastagem ou N-Milho), na dose de $200 \mathrm{~kg}_{\text {de }} \mathrm{N} \mathrm{ha}^{-1}$. A altura do pasto foi regulada por meio de pastejo com lotação contínua e taxa de lotação variável de novilhos de corte. Em média, a massa de forragem foi menor na altura do pasto de $10 \mathrm{~cm}$, entretanto essa massa de forragem foi composta por uma maior proporção de folhas de azevém e menor proporção de material morto em relação ao tratamento com $25 \mathrm{~cm}$. A adubação nitrogenada realizada diretamente na fase pastagem (N-Pastagem) aumentou a massa de forragem, a densidade populacional de perfilhos, a participação de azevém e a porcentagem de folhas de azevém na massa de forragem. Além disso, a adubação nitrogenada na fase pastagem aumentou a taxa de acúmulo de forragem em $69 \%$, evidenciando que não há efeito significativo da adubação feita na lavoura de milho sobre a produtividade de forragem. $\mathrm{O}$ efeito residual da adubação nitrogenada na fase lavoura (milho) não foi suficiente para manter o alto acúmulo de forragem. Dessa forma, a adubação nitrogenada da fase pastagem em sistema ILP é fundamental para manter esses sistemas de produção agrícola e pecuária altamente produtivos.

PALAVRAS-CHAVE: Avena strigosa Schreb. Composição botânica. Lotação contínua. Lolium multiflorum Lam. Ciclagem de nutrientes.

\section{REFERENCES}

AGUinAGA, A. A. Q.; CARVAlHO, P. C. F.; ANGHINONI, I.; PILAU, A.; AGUINAGA, A. J. Q.; GIANLUPPI, G. D. F. Componentes estruturais e produção de forragem de uma pastagem de aveia e azevém submetida a diferentes alturas de manejo. Revista Brasileira de Zootecnia, v. 37, n. 9, p. 1523-1530, 2008. https://doi.org/10.1590/S1516-35982008000900002

AIOLFI, R. B.; SOARES, A. B.; ADAMI, P. F.; PITTA, C. S. R.; KAGIMURA, L. T.; LIMA, A. C.; SCHMALZ, B. A. H. Dinâmica de produção de forragem de cultivares de azevém anual submetidos ao regime de cortes em diferentes locais de avaliação. Revista Sodebras, v. 10, p. 193-196, 2015.

ALVARES, C. A.; STAPE, J. L.; SENTELHAS, P. C.; GONÇALVES, J. L. M.; SPAROVEK, G. Köppen's climate classification map for Brazil. Meteorologische Zeitschrift, v. 22, n.6, p. 711-728, 2013. https://doi.org/10.1127/0941-2948/2013/0507

ANGHINONI, I.; CARVALHO, P. C. F.; COSTA, S.E.V.G.A. Abordagem sistêmica do solo em sistemas integrados de produção agrícola e pecuária no subtrópico brasileiro. Tópicos em Ciência do Solo, v. 8, p. 325 $380,2013$.

APOLINÁRIO, V. X. O.; DUBEUX JR, J. C. B.; MELLO, A. C. L.; VENDRAMINI, J. M. B.; LIRA, M. A.; SANTOS, M. V. F.; MUIR, J. P. Litter decomposition of signalgrass grazed with different stocking rates and nitrogen fertilizer levels. Agronomy Journal, v. 106, n. 2, p. 622-627, 2014.

https://doi.org/10.2134/agronj2013.0496

ASSMANN, T. S.; RONZELLI JÚNIOR, P.; MORAES, A.; ASSMANN, A. L.; KOEHLER, H. S.; SANDINI, I. Rendimento de milho em área de Integração Lavoura-Pecuária sob o sistema plantio direto, em presença e ausência de trevo branco, pastejo e nitrogênio. Revista Brasileira de Ciência do Solo, v. 27, p. 675-683, 2003. https://doi.org/10.1590/S0100-06832003000400012

ASSMANN, A. L.; PELISSARI, A.; DE MORAES, A.; ASSMANN, T. S.; DE OLIVEIRA, E. B.; SANDINI, I. Produção de gado de corte e acúmulo de matéria seca em sistema de Integração Lavoura-Pecuária em presença e ausência de trevo branco e nitrogênio. Revista Brasileira de Zootecnia, v. 33, n. 1, p. 37-44, 2004. https://doi.org/10.1590/S1516-35982004000100006

ASSMANN, J. M.; ANGHINONI, I.; MARTINS, A. P.; COSTA, S. E. V. G. A.; CECAGNO, D.; CARLOS, F. S.; CARVALHO, P. C. F. Soil carbon and nitrogen stocks and fractions in a long-term integrated crop- 
livestock system under no-tillage in southern Brazil. Agriculture, Ecosystems and Environment, v. 190, p. 52-59, 2014. https://doi.org/10.1016/j.agee.2013.12.003

ASSMANN, J. M.; ANGHINONI, I.; MARTINS, A. P.; COSTA, S. E. V. G. A.; KUNRATH, T. R.; BAYER, C.; CARVALHO, P. C. F.; FRANZLUEBBERS, A. J. Carbon and nitrogen cycling in an integrated soybeanbeef cattle production system under different grazing intensities. Pesquisa agropecuária brasileira, v. 50, $\mathrm{n}$. 10, p. 967-978, 2015. https://doi.org/10.1590/S0100-204X2015001000013

ASSMANN, J. M.; MARTINS, A. P.; ANGHINONI, I.; DENARDIN, L. G. O.; NICHEL, G. H.; COSTA, S. E. V. G. A; FRANZLUEBBERS, A. J. Phosphorus and potassium cycling in a long-term no-till integrated soybean-beef cattle production system under different grazing intensities in subtropics. Nutrient Cycling in Agroecosystems, v. 108, p. 21-33, 2017. https://doi.org/10.1007/s10705-016-9818-6

BALBINOT JUNIOR, A. A.; MORAES, A.; VEIGA, M.; PELISSARI, A.; DIECKOW, J. Integração lavourapecuária: intensificação de uso de área agrícolas. Ciência Rural, v. 39, n. 6, p. 1925-1933, 2009.

https://doi.org/10.1590/S0103-84782009005000107

BASSO, K. C.; CECATO, U.; LUGÃO, S. M. B.; GOMES, J. A. N.; BARBERO, L. M.; MOURÃO, G. B. Morphogenesis and dynamics of tillering in a pasture of Panicum maximum Jacq. cv. IPR- 86 Millennium under increasing doses of nitrogen. Revista Brasileira de Saúde e Produção Animal, v. 11, p. 976-989, 2010.

BERNARDON, A.; ASSMANN, T. S.; SOARES, A. B.; FRANZLUEBBERS, A.; MACCARI, M.; DE BORTOLLI, M. A. Carryover of $\mathrm{N}$-fertilization from corn to pasture in an integrated crop-livestock system. Archives of Agronomy and Soil Science, v. 66, p. 1-16, 2020.

https://doi.org/10.1080/03650340.2020.1749268

CAMINHA, F. O.; DA SILVA, S. C.; PAIVA, A. J.; PEREIRA, L. E. T.; MESQUITA, P.; GUARDA, V. D. Stability of tiller population of continuously stocked marandu palisade grass fertilized with nitrogen. Pesquisa Agropecuária Brasileira, v. 45, p. 213-220, 2010.

CARVALHO, P. C. F.; MORAES A.; PONTES L. S.; ANGHINONI I.; SULC R. M.; BATELLO C. Definições e terminologias para Sistema Integrado de Produção Agropecuária. Revista Ciência Agronômica, v. 45, n. 5, p. 1040-1046, 2014. https://doi.org/10.1590/S1806-66902014000500020

CARVALHO, P. C. F.; PETERSON, C. A.; NUNES, P. A. A.; MARTINS, A. P.; DE SOUZA FILHO, W.; BERTOLAZI, V. T.; KUNRATH, T. R.; DE MORAES, A.; ANGHINONI, I. Animal production and soil characteristics from integrated crop-livestock systems: toward sustainable intensification. Journal of Animal Science, v. 96, n. 8, p. 3513-3525, 2018. https://doi.org/10.1093/jas/sky085

CASAGRANDE, D. R.; RUGGIERI, A. C.; JANUSCKIEWICZ, E. R.; GOMIDE, J. A.; REIS, R. A.; VALENTE, A.L.S. Características morfogênicas e estruturais do capim-marandu manejado sob pastejo intermitente com diferentes ofertas de forragem. Revista Brasileira de Zootecnia, v. 39, n. 10, p. 2108-2115, 2010. https://doi.org/10.1590/S1516-35982010001000002

CAUDURO, G. F.; CARVALHO, P. C. F.; BARBOSA, C. M. P.; LUNARDI, R.; NABINGER, C.; GONÇALVES, E. N.; DEVINCENZI, T. Variáveis morfogênicas e estruturais de azevém (Lolium multiflorum Lam.) manejada sob diferentes intensidades e métodos de pastejo. Revista Brasileira de Zootecnia, v. 35, $\mathrm{n}$. 4, p. 1298-1307, 2006. https://doi.org/10.1590/S1516-35982006000500007

DA SILVA, S. C.; SBRISSIA, A. F.; PEREIRA, L. E. T. Ecophysiology of C4 Forage Grasses-Understanding Plant Growth for Optimising Their Use and Management. Agriculture, v. 5, p. 598-625, 2015. https://doi.org/10.3390/agriculture5030598

EMPRESA BRASILEIRA DE PESQUISA AGROPECUÁRIA (EMBRAPA). Sistema Brasileiro de Classificação dos Solos. 3rd ed. Rio de Janeiro: Embrapa Solos, 2013. 
FONTANELLI, R. S.; DOS SANTOS, H. P.; FONTANELI, R. S.; DE OLIVEIRA, J. T.; LEHMEN, R. I.; DREON, G. Gramíneas forrageiras anuais de inverno. In: FONTANELLI, R. S.; DOS SANTOS, H. P.; FONTANELI, R. S. (Eds.). Forrageiras para integração lavoura-pecuária-floresta na região sul brasileira. 2 ed. Brasília, DF: Embrapa, 2012. p. 127-172.

GUNTIÑAS, M. E.; LEIRÓS, M. C.; TRASAR-CEPEDA, C.; GIL-SOTRES, F. Effects of moisture and temperature on net soil nitrogen mineralization: a laboratory study. European Journal of Soil Biology, v. 48, p.73-80, 2012. https://doi.org/10.1016/j.ejsobi.2011.07.015

KLINGMAN, D. L.; MILES, S. R.; MOTT, G. O. The cage method for determining consumption and yield of pasture herbage. Journal of the Animal Society of Agronomy, v. 35, n. 9, p. 739-746, 1943.

https://doi.org/10.2134/agronj1943.00021962003500090001x

KUNRATH, T. R.; NUNES, P. A. A.; SOUZA FILHO, W.; CADENAZZI, M.; BREMM, C.; MARTINS, A. P.; CARVALHO, P. C. F. Sward height determines pasture production and animal performance in a long-term soybean-beef cattle integrated system. Agricultural Systems, v. 177, p. 1-8, 2020.

https://doi.org/10.1016/j.agsy.2019.102716

LEMAIRE, G.; CHAPMAN, D. F. Tissue flows in grazed plant communities. In: HODGSON, J.; ILLIUS, A. W. (Eds.). The ecology and management of grazing systems. Wallingford, UK: CAB International, 1996. p. 3-36.

LEMAIRE, G.; AGNUSDEI, M. Leaf tissue turnover and efficiency of herbage utilization. In: LEMAIRE, G.; HODGSON, H.; MORAES, A.; NABINGER, C.; CARVALHO, P. C. F. (Eds.) Grassland ecophysiology and grazing ecology. Wallingford, UK: CAB International, 1999. p. 265-287.

https://doi.org/10.1079/9780851994529.0265

LUPATINI, G. C.; RESTLE, J.; VAZ, R. Z.; VALENTE, A. V.; ROSO, C.; VAZ, F. N. Produção de bovinos de corte em pastagem de aveia preta e azevém submetida à adubação nitrogenada. Ciência Animal Brasileira, v. 14, n. 2, p. 164-171, 2013. https://doi.org/10.5216/cab.v14i2.21068

MAZZILLI, S. R.; KEMANIAN, A. R.; ERNST, O. R.; JACKSON, R. B.; PIÑEIRO, G. Priming of soil organic carbon decomposition induced by corn compared to soybean crops. Soil Biology and Biochemistry, v. 75, p. 273-281, 2014. https://doi.org/10.1016/j.soilbio.2014.04.005

MCNAUGHTON, S. J. Compensatory plant growth as a response to herbivory. Oikos, v. 40, p. 329-336, 1983. https://doi.org/10.2307/3544305

MORAES, A.; CARVALHO, P. C. F.; ANGHINONI, I.; LUSTOSA, S. B. C.; COSTA, S. E. V. G. A.; KUNRATH, T. R. Integrated crop-livestock systems in the Brazilian subtropics. European Journal of Agronomy, v. 57, p. 4-9, 2014. https://doi.org/10.1016/j.eja.2013.10.004

MÜLLER, L.; MANFRON, P. A.; MEDEIROS, S. L. P.; STRECK, N. A.; MITTELMMAN, A.; DOURADO NETO, D.; BANDEIRA, A. H.; MORAIS, K. P. Temperatura base inferior e estacionalidade de produção de genótipos diplóides e tetraplóides de azevém. Ciência Rural, v. 39, n. 5, p. 1343-1348, 2009.

https://doi.org/10.1590/S0103-84782009005000098

PELlEGRINI, L. G.; MONTEIRO, A. L. G.; NEUMANN, M.; MORAES, A.; PELLEGRINI, A. C. R. S.; LUSTOSA, S. B. C. Produção e qualidade de azevém-anual submetido a adubação nitrogenada sob pastejo por cordeiros. Revista Brasileira de Zootecnia, v. 39, n. 9, p. 1894-1904, 2010. https://doi.org/10.1590/S151635982010000900006 
Does the residual...

BERNARDON, A. et al.

PEREIRA, L. E. T.; PAIVA, A. J.; GUARDA, V. D. A.; PEREIRA, P. M.; CAMINHA, F. O.; SILVA, S. C. DA. Herbage utilisation efficiency of continuously stocked marandu palisade grass subjected to nitrogen fertilisation. Scientia Agricola, v. 72, n. 2, p. 114-123, 2015. https://doi.org/10.1590/0103-9016-2014-0013

PONTES, L. S.; NABINGER, C.; CARVALHO, P. C. F.; TRINDADE, J. K.; MONTARDO, D. P.; DOS SANTOS, R. J. Variáveis morfogênicas e estruturais de Azevém Anual (Lolium multiflorum Lam.) manejado em diferentes alturas. Revista Brasileira de Zootecnia, v. 32, n. 4, p. 814-820, 2003.

https://doi.org/10.1590/S1516-35982003000400005

PONTES, L. S.; CARVALHO, P. C. F.; NABINGER, C.; SOARES, A. B. Fluxo de biomassa em pastagens de azevém anual (Lolium multiflorum Lam.) manejadas em diferentes alturas. Revista Brasileira de Zootecnia, v. 33, n. 3, p. 529-537, 2004. https://doi.org/10.1590/S1516-35982004000300002

PORTELA, J. N.; PEDREIRA, C. G. S.; BRAGA, G. J. Demografia e densidade de perfilhos de capimbraquiária sob pastejo em lotação intermitente. Pesquisa Agropecuária Brasileira, v. 46, n. 3, p. 315-322, 2011. https://doi.org/10.1590/S0100-204X2011000300013

RIBEIRO, R. H.; IBARR, M. A.; BESEN, M. R.; BAYER, C.; PIVA, J. T. Managing grazing intensity to reduce the global warming potential in integrated crop-livestock systems under no-till agriculture. European Journal of Soil Science, p. 1-12, 2019. https://doi.org/10.1111/ejss.12904

ROMAN, J.; DA ROCHA, M. G.; PIRES, C. C.; ELEJALDE, D. A. G.; KLOSS, M. G.; OLIVEIRA NETO, R. A. Comportamento ingestivo e desempenho de ovinos em pastagem de azevém anual (Lolium multiflorum Lam.) com diferentes massas de forragem. Revista Brasileira de Zootecnia, v. 36, n. 4, p. 780-788, 2007. https://doi.org/10.1590/S1516-35982007000400005

SANDINI, I. E.; DE MORAES, A.; PELISSARI, A.; NEUMANN, M.; FALBO, M. K.; NOVAKOWISKI, J. H. Efeito residual do nitrogênio na cultura do milho no sistema de produção integração lavoura-pecuária. Ciência Rural, v. 41, n. 8, p. 1315-1322, 2011. https://doi.org/10.1590/S0103-84782011005000099

SARTOR, L. R.; SANDINI, I. E.; ADAMI, P. F.; NOVAKOWISKI, J. H.; RUTHES, B. E. S. Corn yield and grain nutritional status in a crop-livestock system with winter/summer nitrogen levels. International Journal of Plant Production, v. 12, p. 309-314, 2018. https://doi.org/10.1007/s42106-018-0028-9

SBRISSIA, A. F.; DA SILVA, S. C. Compensação tamanho/densidade populacional de perfilhos em pastos de capim-marandu. Revista Brasileira de Zootecnia, v. 37, n. 1, p. 35-47, 2008. https://doi.org/10.1590/S1516$\underline{35982008000100005}$

SILVA, F. D.; AMADO, T. J. C.; BREDEMEIER, C.; BREMM, C.; ANGHINONI, I.; CARVALHO, P. C. F. Pasture grazing intensity and presence or absence of cattle dung input and its relationships to soybean nutrition and yield in integrated crop-livestock systems under no-till. European Journal of Agronomy, v. 57, p. 84-91, 2014. https://doi.org/10.1016/j.eja.2013.10.009

SIMPSON, J. R.; STOBBS, T. H. Nitrogen supply and animal production from pastures. In: MORLEY, F. H. W. (Ed). Grazing animals. Amsterdam: Elsevier, 1981. p. 261-288. 